\title{
The Relationship with Food in Eating Disorders
}

\author{
Arlene Leite Nunes \\ Universidade da Região de Joinville - Univille, \\ Brazil
}

\section{Introduction}

Lately, there has been an increasing movement of valorization of having in detriment of being, in which people are more valued by what they own than by what they are. This, associated with a transformation in the view of the human being and the world, where more and more the appearance has a higher importance, this trend is a fertile ground to increase eating disorders (ED), that are extremely connected to the super valued esthetic model from nowadays (Assumpção, 2004).

ED's constitute in a group of diseases that affect, mainly, female teenagers and young adults, producing strong biological, psychological and social damages and, consequently, propitiating the increase of morbidity and mortality rates in this population (Cordás, 2004).

In terms of magnitude and prevalence, ED's can be considered emergent diseases, typical from post-modern society. It is estimated that, every year, millions of people are affected by some kind of ED. From these, more than $90 \%$ are female teenagers (Castro \& Goldstein, 1995; Cintra \& Fisberg, 2004; Cordás, 2004; Dietz, 1990).

Because of this increasing incidence, these disorders demand prevention and treatment in all possible ways. They are one of the mental disorders that kill the most in the world whether by malnutrition, heart problems and even suicide. In most cases, the person with the disorder does not consider herself sick, refusing, this way, any treatment, even with the appearance of comorbidities.

In the United States of America, according to Fischer et al. (1995), ED's constitute the third most prevalent non-transmissible chronic disease among teenagers, staying only behind obesity and asthma. Dietz (1990) confirms this claiming that anorexia nervosa (AN) and bulimia nervosa $(\mathrm{BN})$ are among the most prevalent nutritional problems in teenagers. In Brazil, epidemiological data of prevalence of these diseases were not found, according to a revision hold. Nunes et al. (2003), claimed that there are not epidemiological researches about the prevalence of ED's, not only in Brazil, but also in all Latin America.

The two main kinds of ED's, classified as AN and BN, share common characteristics that make them similar, as well as characteristics of their own that make them different. However, the eating patterns that each person with an ED will develop is a singular phenomenon. The kind of food, the frequency of consumption, the ingested amount and other eating characteristics present a specific and individual behavior. It is necessary then, to face each person that manifests these disorders as a unique human being. It is essential to 
suspend preestablished conceptions about what it is or how an ED should manifest, trying to comprehend the person from her own experiences (Beumont, 2002; DSM-IV-TR, 2002).

The testimony of a twenty-three year old lady, ex-anorectic patient, in an interview to Juste (2004, pp.75) shows us the importance of comprehending ED's: "What people need to understand is that $A N, B N$ and binge eating are diseases and they need to be treated like that. A girl with AN needs to be taken serious as well as a girl with cancer must be. It's not under her power stop felling fat, vomiting, fasting, as well as it is not under the power of the girl with cancer make her tumor disappear".

This testimony is an example of how ED's have not been seen or comprehended with the seriousness they deserve yet, what raises difficulties and delays the search by medical, psychological and nutritional help, fundamental in the case of these disorders. The lack of knowledge and/or acceptance of these disorders as sickness harm even more the person with the disease, what might even lead her to death.

The awareness of some of these theoretical data, as well as the increase of the incidence of these disorders and their seriousness, caused the interest in making a deeper study about this theme. And we did it in a different way: meeting the teenagers with these disorders and listening to them, allowing them to speak.

We observe that, in general, researches have discussed these disorders from approaches that are sometimes interpretative and generalizable. We believe that it is important to comprehend and make a deeper study about ED's from their own experience. Therefore, the present study intended to allow teenagers with ED's to speak, trying to comprehend the meaning of the experience lived by them, attempting to answer the following question "What is the meaning of the experience lived by female teenagers with AN and BN, with emphasis in the aspects related to eating?".

In order to reach it, seven female teenagers were interviewed, all of them diagnosed with AN or BN, according to DSM-IV-TR (2002), they were being taken care in the city of Florianópolis, Santa Catarina, Brazil, aged between 17 to 20 .

During the analysis of the interview (that followed the qualitative method, in a phenomenological approach), we tried to identify signification units, categorizing them to reach the general structure of the experience, extracting from this the structure of the lived experience.

This study was hold wishing to comprehend not only what happens in the body of a person, but also what happens in the emotional side: the human being is a whole, so he must be seen and comprehended as a whole. The human being is not just a being that feels. Or just a being that eats. He is a being that feels and eats. Therefore, it is not possible to study ED's isolated from the person that is suffering it, neither the person isolated from his environment. People with AN and BN do not usually have these behaviors only related to food, they relate this way toward life and feelings. They are a whole.

\section{Methods}

This research was characterized as a qualitative research, having a phenomenological approach focusing on the lived experience of female adolescents with ED's. 
The research was held in Florianópolis (Santa Catarina, Brazil), involving seven female teenagers diagnosed with ED's, according to DSM-IV-TR (2002), of whom four of them with $\mathrm{AN}$ and three of them with $\mathrm{BN}$, aged between 17 and 20 years old, attended in Joana de Gusmão Childhood Hospital, at Regional Medical Clinic and in private clinics. The interviews were conducted from March to May of 2006, until reaching the criterion of saturation, which is the phenomenon that occurs when a number of collected data fail to present something new to the phenomenological understanding (Mucchielli, 1991, as cited in Coppe, 2001).

The inclusion criteria in this study were age, sex and diagnosis of the disorder in question. In addition, participants should allow the understanding of the guiding question, take up the case, communicate without hindrance or limitations, have the consent of parents or guardians to participate and accept the condition of having their interviews recorded.

The interviews were conducted according to a predefined script, consisting of an objective part, trying to collect data for characterization of the interviewees, and a subjective part, with questions that varied according to the course of the interview, trying to capture the lived experience of the interviewees about the ED's. The interviews were conducted by the researcher, at the location where the adolescents received care, and lasted 37 minutes on average, ranging from 23 to 58 minutes.

The interviews were recorded and transcribed verbatim by the researcher. Confidentiality and anonymity were guaranteed for the content in order to preserve the identity of the interviewees who chose a cognomen to be used throughout the interview and signed a Free and Informed Consent Form for participation in this research.

After the transcription, to begin the analysis of the interviews, the steps outlined in the proposal of Amedeo Giorgi were followed (Amatuzzi, 1996; Coppe, 2001; França, 1989; Holanda, 2002, 2003; Martins \& Bicudo, 2003; Moreira, 2002), divided in: 1) reading the interview transcripts, with the intention of capturing the sense in all, before the object of research, 2) new reading of the text, with the specific objective of discriminating signification units with a psychological perspective, capturing the moments of sensitive psychological change of each situation, 3) transformation of units in psychological language, in order to reach the most straightforward and explicit expressions as possible to the perceptions contained in the expression of the subject, 4) synthesis of all the signification units, turning them into a consistent report on the experience of the subject, reaching the structure of the experience.

Having finished this step, in order to continue with the analysis of the data, the following methodological paths described by Coppe (2001) were performed: 1) creation of a table containing the identification data of each participant, a description of the signification units and the psychological understanding of each one, allowing us to observe the specific synthesis of each participant, 2) categorization of the signification units in order to comprehend the overall structure of background, then extracting the structure of the lived experience, 3) development of a general synthesis, consisting of the analysis of all reports, to obtain an overview of the material. From this summary, we had a reflexive dialogue, linking empirical and theoretical content that guided our investigation. 
The research project was approved by the Ethics Committee in Human Research of Universidade Federal de Santa Catarina ${ }^{1}$ (Project No. 013/06) and of Joana de Gusmão Childhood Hospital (Project No. 016/2006).

\section{The relationship with food in the perception of the adolescents}

\subsection{Brief profile of the adolescents interviewed}

Table 1 presents a brief profile of the seven teenagers interviewed, trying to list some information considered important for a better understanding of the phenomenon studied.

The current age of the adolescents interviewed ranged between seventeen and twenty years old. The World Health Organization (WHO, 2005) considers adolescence the period between ten and nineteen years old, but some authors consider that there are many individual variations, influenced by both genetic and sociocultural factors that make age limits of the stages of adolescence approximate. Thus, for these authors, the increasing complexity of the teen phenomenon goes beyond the second decade since the technological development of Western society has led it to an extension of this transitional process. They therefore consider that the final or tardy phase can go up to twenty years of age (Chipkevitch, 1995; Vieira, 2002).

Regarding the type of ED and the treatment phase, of seven adolescents interviewed, four had diagnosis of AN (Gabriela, Carolina, Camila and Paula) and three had diagnosis of BN (Daniela, Helena and Julia). One of them is under treatment, but does not admit she has an ED and is in critical condition (Gabriela), three are under treatment and admit to having an ED (Daniela, Julia and Helena), two are under treatment in the recovery phase (Caroline and Paula) and one is not under treatment, and admits she has an ED and needs treatment (Camila).

\begin{tabular}{|c|c|c|c|c|}
\hline Cognomen & $\begin{array}{l}\text { Current } \\
\text { age (yrs) }\end{array}$ & Education & $\begin{array}{l}\text { Type of } \\
\text { ED }\end{array}$ & Phase of the ED \\
\hline \begin{tabular}{|l|} 
Daniela \\
\end{tabular} & 17 & High School & BN & $\begin{array}{l}\text { Under treatment, admits she has } \\
\text { ED }\end{array}$ \\
\hline Gabriela & 17 & $\begin{array}{l}2^{\text {nd }} \text { year High } \\
\text { School }\end{array}$ & AN & $\begin{array}{l}\text { Under treatment, does not admit } \\
\text { she has ED (in critical condition) }\end{array}$ \\
\hline Helena & 17 & $\begin{array}{l}3^{\text {rd }} \text { year High } \\
\text { School }\end{array}$ & $\mathrm{BN}$ & $\begin{array}{l}\text { Under treatment, admits she has } \\
\text { ED }\end{array}$ \\
\hline Carolina & 19 & $\begin{array}{l}\text { Incomplete Higher } \\
\text { Education }\end{array}$ & AN & $\begin{array}{l}\text { Under treatment, in recovery } \\
\text { phase }\end{array}$ \\
\hline Julia & 20 & High School & $\mathrm{BN}$ & $\begin{array}{l}\text { Under treatment, admits she has } \\
\text { ED }\end{array}$ \\
\hline Camila & 20 & $\begin{array}{l}\text { Incomplete Higher } \\
\text { Education }\end{array}$ & AN & $\begin{array}{l}\text { Stopped treatment, admits she has } \\
\text { ED }\end{array}$ \\
\hline Paula & 20 & $\begin{array}{l}\text { Incomplete Higher } \\
\text { Education }\end{array}$ & AN & $\begin{array}{l}\text { Under treatment, in recovery } \\
\text { phase }\end{array}$ \\
\hline
\end{tabular}

Table 1. Brief profile of the adolescents

\footnotetext{
${ }^{1}$ Santa Catarina Federal University
} 
With respect to the treatment location, one of them (Gabriela) came from Joana de Gusmão Childhood Hospital (HIJG), four (Daniela, Carolina, Julia and Camilla) from Regional Medical Clinic and two (Helena and Paula) from private clinics. Although the teenagers interviewed were found at the age between seventeen and twenty years old, the disorder manifested between eleven and eighteen years old, and the duration of disorder was between one and nine years. As to education, all of them are between high school and incomplete higher education.

Table 2 presents data related to the anthropometric characteristics of the interviewees, regarding height, weight and body mass index (BMI). One of the most common criteria used in ED's to determine whether a person is below the expected minimum weight is the BMI, calculated as weight in kilograms divided by height in meters ${ }^{2}$ (DSM-IV-TR, 2002). Although this criterion presents some limitations, it is the most practical and the least costly one to analyze individuals and populations, and thus widely used (Conde \& Monteiro, 2006).

According to the WHO (2006) classification criteria, a BMI below $18.50 \mathrm{~kg} / \mathrm{m}^{2}$ is already considered underweight, as rates between 17.00 and $18.49 \mathrm{~kg} / \mathrm{m}^{2}$ are considered mild underweight, between 16.00 and $16.99 \mathrm{~kg} / \mathrm{m}^{2}$ are considered moderate underweight and severe underweight rates below $16.00 \mathrm{~kg} / \mathrm{m}^{2}$. The rates between 18.50 and $24.99 \mathrm{~kg} / \mathrm{m}^{2}$ are considered normal weight, those above $25 \mathrm{~kg} / \mathrm{m}^{2}$, overweight. For diagnostic criteria of ED's, it is considered the BMI less than $17.50 \mathrm{~kg} / \mathrm{m}^{2}$ (DSM-IV-TR, 2002).

Based on the data from Table 2, one can see that, of the adolescents diagnosed with AN (Carolina, Paula, Camila and Gabriela), two (Gabriela and Carolina) continue with a BMI below $18.5 \mathrm{~kg} / \mathrm{m}^{2}$, one (Paula ), who is in the process of recovery, presents a normal BMI, and one (Camilla) has no values for not having informed the current weight. Only one (Gabriela) remains below the BMI of $17.50 \mathrm{~kg} / \mathrm{m}^{2}$, the teenager who does not admit to having an ED, lying in a state considered serious.

Observing the minimum weight reached, we found that all four adolescents diagnosed with AN (Carolina, Paula, Camila and Gabriela) are found with a BMI below to what is considered normal $\left(18.50\right.$ and $\left.24.99 \mathrm{~kg} / \mathrm{m}^{2}\right)$. In addition, three of them (Carolina, Paula and Gabriela) have BMI below $16.00 \mathrm{~kg} / \mathrm{m}^{2}$, and are thus in a state of severe underweight (WHO, 2006).

It is also interesting to note that when it comes to the maximum weight reached, none of the four (Carolina, Paula, Camila and Gabriela) exceeded the normal BMI, and the highest rate reached was of $23.01 \mathrm{~kg} / \mathrm{m}^{2}$, very far from the upper limit of normal weight $\left(24.99 \mathrm{~kg} / \mathrm{m}^{2}\right)$. In addition, one of the adolescents (Gabriela), even when she reached her maximum weight, was still below to what is considered normal and within the range of ED's. The maximum BMI reached was $17.35 \mathrm{~kg} / \mathrm{m}^{2}$.

By observing the weight loss of these adolescents diagnosed with AN, we found a drop of 20.83 (Carolina) to $44.74 \%$ (Gabriela) of weight, and the minimum amount of weight loss was $10 \mathrm{~kg}$ (Carolina ) and the maximum was $19 \mathrm{~kg}$ (Paula).

With respect to the adolescents diagnosed with BN (Daniela, Julia and Helena), we observed that all of them are currently with normal BMI, and only one (Daniela) had the BMI below normal, when considering the minimum weight. It is noteworthy that the teenager in 
question was initially diagnosed with $\mathrm{AN}$, who later developed $\mathrm{BN}$, thus confirming the data found in the literature that show that about $70 \%$ of people with $\mathrm{BN}$ maintain the weight within what is considered normal (Appolinário \& Claudino, 2000; Cordás et al., 2004).

Concerning the maximum weight reached, only one of the adolescents (Julia) reached a rate considered overweight (above $25 \mathrm{~kg} / \mathrm{m}^{2}$ ), while the others (Daniela, Helena) had, as well as the adolescents diagnosed with AN, normal BMI, also quite far from the upper limit of normal weight, and the maximum rate achieved was $21.63 \mathrm{~kg} / \mathrm{m}^{2}$, lower than the one found in the maximum rate of anorexia.

Regarding the weight loss of these adolescents diagnosed with $\mathrm{BN}$, we found a drop of 9.26 (Helena) to $25.76 \%$ (Julia) weight, being that the minimum amount of weight loss was $5 \mathrm{~kg}$ (Helena) and the maximum was $17 \mathrm{~kg}$ (Julia), confirming that there is a significantly greater weight loss in AN rather than in BN (Cordás et al., 2004).

\begin{tabular}{|l|l|l|l|l|l|l|l|}
\hline Cognomen & $\begin{array}{l}\text { Height* } \\
(\mathrm{m})\end{array}$ & $\begin{array}{l}\text { Current } \\
\text { weight* } \\
(\mathrm{kg})\end{array}$ & $\begin{array}{l}\text { Minimum } \\
\text { weight* } \\
(\mathrm{kg})\end{array}$ & $\begin{array}{l}\text { Maximum } \\
\text { weight* } \\
(\mathrm{kg})\end{array}$ & $\begin{array}{l}\text { Weight* } \\
\text { loss } \\
(\mathrm{kg})\end{array}$ & $\begin{array}{l}\text { Weight* } \\
\text { loss } \\
(\%)\end{array}$ & $\begin{array}{l}\text { Current } \\
\mathrm{BMI}^{*} \\
\left(\mathrm{~kg} / \mathrm{m}^{2}\right)\end{array}$ \\
\hline Daniela & 1.62 & 52 & 46 & 54 & 8 & 14.81 & 19.81 \\
\hline Gabriela & 1.48 & 38.3 & 21 & 38 & 17 & 44.74 & 17.48 \\
\hline Helena & 1.58 & 54 & 49 & 54 & 5 & 9.26 & 21.63 \\
\hline Carolina & 1.59 & 45 & 38 & 48 & 10 & 20.83 & 17.80 \\
\hline Julia & 1.52 & 52.5 & 49 & 66 & 17 & 25.76 & 22.72 \\
\hline Camila & 1.51 & does not know & 37 & 50 & 13 & 26.00 & - ----- \\
\hline Paula & 1.56 & 48 & 37 & 56 & 19 & 33.93 & 19.72 \\
\hline
\end{tabular}

* Data on weight and height were reported by adolescents

** BMI was calculated based on the anthropometric data reported

Table 2. Anthropometric characteristics of the adolescents

\subsection{The content of the interviews and signification units}

With respect to the guiding question of how female adolescents with ED's perceive and experience their relationship with food, the analysis of the interviews brought out nine signification units, namely: what food represents, eating habits, foods that are no longer eaten, food that came to be consumed, the consumption of soft drinks, food choices, meal composition, the family's eating habits and healthy food.

\subsubsection{What food represents}

The term food, in the vernacular sense, means: "1. What you eat or is suitable for eating. 2. Action of eating" (Ferreira, 1993, pp.131). But for the teenagers interviewed in this research, in most cases, food had a very different meaning, referring to something negative, as we found in the reports below:

\footnotetext{
"Hum, well, torture." (Daniela)

"It represented fear, so I was afraid." (Carolina)

"I think it is a very bad thing." (Gabriela)
} 
"Escape, a decadence, drugs." (Helena)

For some of the teenagers interviewed, the food was an obligation, something that would take their freedom, described as follows:

"It is necessary, mandatory, but I did not want it to be like this." (Julia)

"If I were not forced to eat, perhaps it might be good." (Gabriela)

"I feel freer when I do not eat." (Helena)

Others commented on the positive side of food:

"While that is good. [...] The foods that you like." (Daniela)

"Food that makes you feel good. [...] The food is good for me today, it's tasty." (Carolina)

With a view to what food represents to these teenagers, we can observe their eating habits.

\subsubsection{Eating habits}

The development of eating habits is influenced by several factors - physiological, psychological, sociocultural, economic - and occurs as the children grow, until the moment when consciously and independently they will choose the food that will be part of their diet. While a child, usually parents determine their food, but as they go to school and socialize with other children, they get to know other foods, preparations and habits (Bandeira et al., 2000).

During adolescence, due to the rapid physical growth and development, there is an increased need for nutrients, but at this stage there is also a change in food preferences, which puts these individuals at a nutritional risk group (Bandeira et al., 2000).

In the interviews that made up this study, we observed, from the adolescents, a concern with food control, both alone and with nutritional counseling, as described below:

"Oh, now I'm going to eat, not now, I won't eat now, I'll wait a little longer, I have to wait some hours to eat breakfast, some hours and I'll have lunch, later in the afternoon I'll have a snack." (Camila)

"Today I see that I was eating all wrong." (Carolina)

"But I eat everything in the right quantity. [...] As I have nutritional counseling with a nutritionist I eat all kinds of food." (Paula)

"So, you know, everything is under control. [...] I am on a diet with a nutritionist now." (Helena)

Some of their reports showed that they intended to adhere to a diet considered healthy by them:

"I'm not a fan of vegetables or greens, or anything like this, I don't eat them. [...] Eating something lighter, though that's not what I like, you see!" (Daniela)

"I simply don't eat as much fat. [...] I like to eat fruits, watermelon. [...] I always eat fresh sandwiches (when I eat at the mall)." (Gabriela) 
"Now I'm really on a diet [...] My meals were kind of reduced. [...] I eat enough fruit as well. [...] I am vegetarian so I have to eat soy and a lot of small protein bars." (Helena)

However, this food considered healthy, is not always preferred by these adolescents, as shown by the following reports:

"I was not eating food, I was eating bread, that's one thing I did not use to eat before, so. [...] I'm eating carbs more often now [...] I like pasta, junk, snacks." (Daniela)

"Like, I used to eat chocolate. [...] Sometimes I felt like eating a truffle and I did, but without feeling guilty." (Carolina)

"But I really like sweets, then I can eat sweets too, I can eat a small chocolate bar a day." (Helena)

"When I was little I used to eat a lot (fast food)." (Gabriela)

It is also interesting to note that many of these teenagers interviewed stressed the fact that they are eating, according to the excerpts below:

"But I'm eating, I'm not quitting food." (Camila)

"I eat everything." (Gabriela)

"But I eat [...] I eat everything I like, such as rice and beans every day." (Paula)

"Beats me, I eat." (Helena)

"I ate bread, I ate meat, rice, everything." (Gabriela)

To proceed with the subject related to food, we may observe then, the foods that are no longer consumed by the adolescents interviewed.

\subsubsection{Foods that are no longer eaten}

Nutrition and diet play an important role in the development and maintenance of ED's, and should thus be taken into account during the treatment plans of such disorders.

People with these disorders have severe dietary restrictions, eating patterns and wrong eating habits due to a number of factors such as myths and false beliefs, feelings of incompetence to deal with food, fear of putting on weight (Alvarenga \& Larino, 2002).

The main foods that are no longer consumed by the adolescents interviewed were those they considered "junk" - chocolate, for example - regardless of whether they liked it or not:

"Chocolate. I like it so much, but I'm not eating. Mostly junk, like this, you know, I limit. [...] Candy, gum, chocolate." (Camila)

"Chocolate. [...] Popcorn, stuff like that, no way." (Carolina)

"I do not like them today (chocolate, candy, potato chips)." (Gabriela)

Besides these, other foods such as bread, fruit and meat are no longer consumed, and these along with fried food have even been linked to negative points by some of the teenagers, as these reports show:

"I do not eat fried food. I still feel sick of fries." (Carolina) 
"I had stopped eating red meat. [...] I stopped eating fried food. [...] I keep thinking it will not do any good for my body." (Paula)

"I had stopped eating bread." (Daniela)

"I stopped eating fruit." (Julia)

In ED's, the relationship with food is so distorted that sometimes it becomes difficult to even describe what they stopped eating, as it happened to this adolescent:

"I can not say that I stopped eating a lot, I lost track of what I eat [...]. It looks like it's just food, there isn't much difference, [...] so I don't know exactly what I can tell you that I stopped eating, what I started eating, it's getting a little complicated." (Helena)

In the study by Dunker \& Philippi (2003), the types of food that were least consumed were soda, chocolate, pasta and potato chips, and those that they least liked were vegetables, meat and fat, consistent with what was found in our research about what was no longer consumed, with the exception of soda. We describe below, the type of food that started to be consumed.

\subsubsection{Food that came to be consumed}

Looking at the most consumed foods in the study by Dunker \& Philippi (2003) among the students with symptoms of AN, we found the presence of some special foods, which by their own qualities, reflect the concern in making a balanced diet, having mainly a variety of fruits and vegetables. In the interviews of this survey we also found the approval of consumption of vegetables by some of the teenagers, whether they like it or not, as shown by the statements below:

"Although I don't like them (vegetables), I have to learn to love them." (Daniela)

"Vegetable is one thing I learned to eat that I don't, I don't, I never realy liked it." (Carolina)

"One thing I started to eat that I didn't use to eat much is vegetable." (Paula)

One of the adolescents surveyed also reported an increased consumption of sweets, as described below:

"I started to eat more sweets" (Helena)

In addition to these foods, the consumption of soda is also notable in the case of adolescents with ED's, as will be seen below.

\subsubsection{The consumption of soft drinks}

Excessive consumption of soft drinks by teenagers is a common problem across the globe (Bandeira et al., 2000), also occurring in adolescents with ED's, as noted in the statements below:

"I woke up at 6 o'clock, then I didn't eat anything, I only had soda, my other addiction... So, it's normal, I didn't eat anything else. [...] I wake up and play on my computer, I'm always on my computer, you know, then I have a soda, anything, and it is hard for me to eat, you know." (Daniela) 
"And a lot of Coke. I drink a lot of soda. By and large, two liters per day. In the morning if I wake up in the morning the first thing I do is drinking a Coke. At dawn, if I wake up and I'm thirsty, I have a Coke. [...] I don't drink water, only in the Coke. It's very rare that I drink water. Only when I take some medicine." (Julia)

We found that soft drink, for these teenagers, sometimes end up replacing meals or water itself, becoming thus one of the food choices made by adolescents. This process of food choice will be observed in the sequence.

\subsubsection{Food choices}

Several factors may be involved in the choice of food, both from signals originated in the brain or on the outer edge when out of habit (Bacaltchuk \& Appolinário, 2005). In our study, some of the factors mentioned by the adolescents interviewed for the food choices were the amount of calories or what is less filling, as described below:

"Usually I'm watching the calories. [...] I'm eating a snack, but I' $m$ watching the calories right there, it's automatic." (Daniela)

"Before, I used to look for less fattening food." (Julia)

"I know what is more caloric, what is less caloric, so when I think I'm a little overweight, I know what I can eat." (Paula)

"On the following day I do something else to eat, you know, not to eat the same again. [...] Not to get fat." (Camila)

In a study conducted by Lobera \& Ríos (2009), where they analyzed the diets chosen by forty-four anorectic patients and thirty-four people without ED, they also found that anorectic patients have a lower fat intake than healthy people, and also the content of carbohydrates, proteins and fats were lower among these people.

Other factors mentioned about their food choices were the cravings, flavor, or taste, as testimonials below:

"If I feel like eating something, I do, but then I feel guilty afterwards [...] I eat because I feel like eating it." (Julia)

"I choose what I eat [...] according to my will." (Paula)

"Mostly because of the taste too." (Daniela)

"There is taste, then, there's that pleasant feeling of eating it." (Carolina)

Another food choice mentioned by the adolescents interviewed were salads and fruits, what matches with the study of Lobera \& Ríos (2009), that showed that vegetables were chosen more often by these patients:

"Sometimes I do not like salad so much, but I used to eat more salad, and less food." (Camila)

"I'd eat a lot of fruit, I would drink juice. [...] I could eat bread, but not rice." (Gabriela)

"My food choice is salad, I'm a vegetarian, I like salad and sweets. I don't know, I could eat it all day long." (Helena) 
During episodes of binge eating that occur in ED's it is possible to happen considering food choices when these episodes are planned. But in most cases, they are not planned, so there is no choice of foods to be eaten (Devoraes \& Fagundes, 2005), which can be confirmed by the testimonies below:

"Oh, I don't choose (compulsion), whatever is there I eat, you know. [...] It is usually what I love." (Julia)

"In binge, [...] that's when I usually eat, I'm hungry, so I'll eat it." (Helena)

One of the professionals needed in a team that works with people with ED's is a nutritionist. His role is closely linked with the factor of food choices, since the nutritional advice is important to clarify and demystify inappropriate beliefs as well as enabling the establishment of a proper relationship with food (Alvarenga \& Larino, 2002). The statements below show the influence of this specialist in food choices on some of the adolescents interviewed:

"The nutritionist who chooses. She also lets me choose, but I prefer her to choose because it is difficult, I don't know what I like." (Gabriela)

"We (she and the nutritionist) tried to make a balanced menu, in the first month I followed a menu strictly, later we started adapting to make some modifications." (Paula)

"I didn't know how to do this before I went to the nutritionist, I didn't know how to eat and stop feeling hungry." (Helena)

We can not unlearn that food choices are complex decisions related to social conditions, cultural traditions and irrational elements, and that eating is also a social activity and food is an emotional issue (Alvarenga, 2004). Furthermore, since the beginning of our lives, food is intertwined with emotions, symbolisms and socioeconomic and cultural influences. Thus, eating infers, for sure, in making choices. But it also involves establishing relationships, relating or not with models and values from the family or others, adapting well or poorly to the established standards and living with habits, schedules and several lifestyles (Eisenstein et al., 2000).

To carry on the issue of food choice, we describe the meals made by the adolescents interviewed, as well as the meal composition.

\subsubsection{Meal composition}

According to the Guia para Escolha de Alimentos² (Philippi, 1999), the eating habits of an individual should be distributed in six meals, arranged as follows: breakfast, morning snack, lunch, afternoon snack, dinner and evening snack. In our survey, the number of meals ranged from 3 to 8 a day. According to Philippi et al. (2000), breakfast should be between 6 and 9 o'clock and make up $25 \%$ of total calories of the day. The teenagers interviewed described their breakfast as follows:

"In the morning I rarely have breakfast, I always wake up late to leave, or something like that, and when I sleep late I skip to lunch." (Daniela)

${ }^{2}$ Guide for the Choice of Food 
"I wake up by noon, I can not wake up early, I wake up and go straight to lunch." (Julia)

"Oh, there's bread (one, one and a half rolls), coffee (one cup), normally like this." (Camila)

"For breakfast I have a slice of bread with jam and light cheese and chocolate milk, coffee with milk." (Carolina)

"There are crackers, bread, fruit and milk." (Gabriela)

"For breakfast I always drink lots of coffee with milk, [...] toast with fruit, or a fruit, or yogurt." (Paula)

"When I'm not on a diet, I have yogurt and a fruit. But now that I'm on a diet, during this last week I can choose between yogurt or a fruit. Just for me to lose weight." (Helena)

Thus, we observed that breakfast for the teens surveyed consists of food considered healthy. The mid-morning snack, also recommended, is not always done, but when it happens, it is also composed of food considered healthy, as evidenced by the statements below:

"Then, sometimes, by 10 o'clock I have some light yogurt, still, everything is light, light yogurt." (Carolina)

"Now I don't have morning snack anymore, I have it all together, I used to have it but now I have everything together." (Gabriela)

"It's a fruit and some yogurt, or a cup of coffee and two pieces of toast, or a small cereal bar, then it depends on if my weight is okay, it depends." (Paula)

"After breakfast I eat a fruit, or a cheese roll during the recess." (Helena)

Lunch should happen between 11 a.m. and 1 p.m., constituting 35\% of total calories of the day - the largest meal of the day (Philippi et al., 2000). With respect to foods consumed for lunch by the adolescents surveyed, we highlight the following statements:

"Usually I make noodles, [...] I have a bagel or something like that." (Daniela)

"Rice, pasta, pretty normal food like that, you know, like meat, but if it's fatty then I have chicken, everything." (Julia)

"But I eat whatever is there, like, beans, rice, meat, potatoes. [...] About three spoonfuls of rice, a little bit of beans. Just a little. A little bit of meat. [...] A little as well. Potatoes, a little, too." (Camila)

"About three spoonfuls of rice, beans, then meat or chicken or fish and vegetables." (Carolina)

"A fruit. [...] I am forced to eat meat, rice and beans. And a plate of salad." (Gabriela)

"Brown rice, then I have fish once a week, [...] then once or twice a week I eat red meat, grilled steak, grilled chicken, roast chicken, beans and salad, a lot of salad." (Paula)

"I have, I don't know, bread." (Helena)

These meals are often prepared by the adolescents themsemves, and this is a fairly common practice in ED's, and this was verified in their statements:

"Usually I make noodles, my mom makes food, but I don't like to eat that." (Daniela) 
"There was some time that I wanted to prepare my lunch to take care of everything so that it was not fatty, or anything that would make me put on weight." (Julia)

"I usually do that (prepare the meals)." (Camila)

Some of the teenagers interviewed "got rid of" food or made excuses for not eating, as shown by the following fragments:

"Sometimes I don't have lunch." (Daniela)

"I'm not hungry ... I don't want to eat now." (Julia)

"I used to say I was not hungry." (Paula)

"I should prepare a plate of food, but I don't have time for that." (Helena)

"When I was in crisis, sometimes, I had lunch earlier, then I would be far away, or sometimes I didn't eat anything, I would give my food to the dog." (Camila)

"At that time I would hide it, I used to run away, I would find a way, I would go to the living room, I pretended to be watching television, I used to put little food on the plate, I would put it in the garbage, or would give it to the dog." (Paula)

Otherwise, the food consumed - when consumed - was mostly in small amounts, as noted in the statements below:

"I don't eat much at lunch. [...] It's the time I eat the least." (Julia)

"Oh, I eat very little, a little bit, like this." (Camila)

The afternoon snack, when they have it, as well as in the morning, also consists of food considered healthy by the adolescents interviewed, according to their reports:

"Sometimes I eat one thing or another. [...] A snack." (Daniela)

"In the afternoon I really don't eat anything. [...] It's very rare for me to eat anything in the afternoon." (Julia)

"As I work, I have lunch, then when I come back, I drink coffee." (Camila)

"I eat at 3 o'clock, before, I didn't use to eat anything, fruit salad or anything like that. Now I eat cookies, or something whole wheat and light, or Social Club ${ }^{\mathrm{TM}}$. [...] In college she (nutritionist) said that I had to eat a little bit, and then I drink coffee with milk. [...] Then at 6 o'clock I get home and have a milk and Ovaltine ${ }^{\mathrm{TM}}$ shake, which the reason is that the shake had to be placed in my meal because some time ago I lost (weight) again, a month ago." (Carolina)

"Milk, juice, crackers and fruit." (Gabriela)

"In the afternoon snack I repeat the morning snack, I make something. [...] At the $6 o^{\prime}$ clock snack too, or I do the breakfast reversed." (Paula)

"There are two snacks, it's a small snack and a regular snack. I can put it all together when I'm on PMS, I can put it all together and eat, but then I don't know, fruit, yogurt, cookie, or bread, may be, there's a variety, like this. Then in a controlled amount." (Helena) 
Dinner should happen between 7 p.m. and 9 p.m., comprising, as breakfast, $25 \%$ of total calories of the day (Philippi et al., 2000). With respect to foods consumed for dinner, the following were the testimonies of the adolescents:

"At night I have a simple snack. [...] Oh, bread, sometimes I add a sausage or margarine, something like that and bread, I don't eat a lot of stuff." (Daniela)

"I usually eat wheat bread with cheese, ham, ricotta cheese and lettuce and tomato. It's healthier. [...] Usually I eat something breaded or a sandwich during break at school, or a bowl of açai with banana." (Julia)

"Then later at night I eat an apple or a cracker." (Camila)

"Then, at 8 pm, when I have dinner, I eat a roll, salad with white cheese or with a chicken patty." (Carolina)

"For dinner I have only milk and fruits." (Gabriela)

"For dinner I make a sandwich, turkey breast, reduced-fat cheese or cottage cheese, bread, and maybe light bread or regular bread, salad, a cup of coffee, a cup of yogurt." (Paula)

"Then I have dinner, usually soy burger, I need to eat it one a day." (Helena)

It is also recommended to have a third snack, commonly called supper, composing, like the other snacks, $5 \%$ of total calories of the day (Philippi et al., 2000). Some of the teenagers interviewed have this meal, as described in the statements below:

"She (nutritionist) recommended that I eat supper, sometimes I eat it, sometimes I don't, because it is an apple or any fruit." (Carolina)

"Supper is also milk and fruit." (Gabriela)

"And for supper usually a cup of coffee with skimmed milk, a banana, it's always something like that." (Paula)

Looking at the descriptions of these meals made by the adolescents interviewed, we found that they actually have a very big concern in maintaining a healthy diet, they eat food that they consider healthy, although sometimes in small quantities or even skipping some meals. Two factors stood out about the weekends. First, waking up late and spending the rest of the day eating "crap", even though many of these teenagers interviewed said that they don't eat, changing thus the pace of all other days of the week, as evidenced by the statements below:

"Then on Sunday I usually sleep until very late, sometimes it's even because of the medication I've been taking, so I sleep the whole day, I wake up at night. [...] I have a soda, [...] I just nibble something. [...] Sunday is a day that I don't eat. [...] A cracker." (Daniela)

"But on Sunday I wake up late, sometimes I sleep until 3 pm on Sunday, then I wake up, I don't eat, otherwise I just eat any crap. [...] Ice cream or any dessert that is in the fridge or a piece of cake, or something like that, then at night I usually have a snack, Sunday is the day that I eat the least." (Julia)

On the other hand, a second factor stands out: some of the teenagers interviewed about their eating habits on the weekend claim to overeat or feel hungrier for they are idle, as shown by these statements: 
"Saturday I eat the most, [...] I wake up at noon, then I have lunch, then I spend the whole Saturday afternoon doing nothing, so I eat everything that comes up." (Julia)

"Over the weekend I'm hungrier because there's nothing to do, I don't work." (Camila)

"On the weekends if I stay at home, I end up getting upset, I end up eating too much." (Helena)

In addition to the meals, there are also the so-called "extras" that would be eating anything that is caloric and different than what they are used to eating in their daily diet, as exemplified in the story of this adolescent:

"Jaque ( nutritionist) kind of forced me to eat an 'extra' during the week as well. An extra, anything like this, a piece of cake, or more over the weekend. [...] But it's so tricky, I always feel kind of guilty." (Carolina)

Once observed these meals contents, we will describe, then the perceptions of these teenagers about the eating habits of their families, as well as the influence of these habits on the eating habits of these adolescents. It is noteworthy to stress that the opposite may also occur: the eating habits of adolescents influencing the family's eating habits.

\subsubsection{The family's eating habits}

From birth, parents have a fundamental role in the development of the eating habits of their children, either by the type of food they offer to their children, or through the food concepts that they express, and all these factors influence the formation of eating habits of children . The way the family organizes their diet - the type, quantity and quality of food - may constitute a risk factor for developing ED's. But in addition, another factor that plays a central role is the relationship that the family establish with food (Cobelo, 2004).

According to a study hold by Prieto (2011), in which fifty-seven relatives of patients with ED participated, the feeding of relatives of these patients with ED wouldn't be healthy either, being in general hypocaloric. The study also showed that when the feed of the patient is compared to the feed of the relative, not big differences are found. In our study most of the adolescents interviewed also found their way to eat similar to their families', as these statements show:

"It is (the family's eating habits similar to hers). A lot of fat, my father is more concerned, you know, but my mother is not, well, she is not fat, but she feels like eating the same things as I do, a lot of pasta, she can't eat only one roll of bread for the afternoon snack, she's always overeating, and sometimes she also spends hours without eating, she eats very little, well, three meals, she wakes up in the morning, she does not eat in the morning, she eats lunch, she eats more for lunch, then she drinks coffee at 6 o'clock, she goes up to 6 p.m. with no food, and then at night she eats something, always a snack, some crap." (Julia)

"My brother has always been into martial arts and this stuff, then he's already been into healthier food, as well, but he eats a lot, he eats a fried egg every day, but he makes a lot of physical activity then. [...] Back home everybody liked fried food like, my mom liked fried chicken. [...] Before we used to eat a lot of crap, like, yellow cheese, [...] my mother has always been a big fan of chocolate, sweets like this, always, always. [...] My father has always been into a more healthy diet, like, his plate, more than half of it is made of salad [...] he's been always like this, into fruits and lots of greens. I have always been interested in fruits, but I always tried to stay away from vegetables and salad, like, it 
would never be on my plate and now it is. [...] Sometimes my mother makes it for my father, because my father likes fried fish, and fried chicken." (Carolina)

"I think it was similar (the family's eating habits similar to hers), but it's not now. I try other ways, I try to eat as little as possible. [...] My family is descendant of Italians, then they're very into pasta and that stuff, so I try not to care much for it. But at home everyone likes to eat. The only problem is that as everybody likes to eat, they also love to compare, they say, 'Oh, because I eat salad, I eat this and I eat that which is good'. Everyone wants to show off saying they have the best nutrition, healthier, [...] I think that everyone at home has an aesthetic concern. [...] My mom's a little overweight, a little bit, she has hypothyroidism, which makes it worse." (Helena)

Under a different aspect, but still on the same topic, some of the teenagers interviewed found their families' eating habits similar to their own way, differing only in quantity, as you can see in the statements below:

"Aham (the family's eating habits similar to hers). [...] The amount does not. [...] My sister occasionally eats dinner, my grandmother has dinner, my uncle who lives with us too, but I kind of eat this little (I eat little, only a small fruit)." (Camila)

"Yes (the family's eating habits similar to hers).[...] No. It's not (eating less and less)." (Gabriela)

"It is. It's much like this (the family's eating habits similar to hers). My family always had the habit of eating lots of vegetables, having meals together at the table and, during the same hours. The only habits that they don't have and I adhered to are the snacks, you know." (Paula)

Some of them also reported that their current eating habits were influenced by the family's eating habits:

"Yes (the way her mother eats influenced her eating habits). Yes, because then I eat whatever she prepares. Then I ended up eating the same things as she does. I eat what she brings from the bakery, then I end up having the same eating habits as hers." (Julia)

"Aham (the way her family eats influenced her eating habits). [...] Like eating, always having bread for breakfast, you know, for lunch we always have rice, beans, you know, some meat. [...] It is more the type of food, the quantity, I've never been into eating too much. [...] They eat well, you know." (Camila)

"For breakfast I always have lots of coffee with milk, as it is one thing I really like, I think it's one thing I inherited from my mother." (Paula)

There was, moreover, a report that according to the adolescent, her eating habits influenced the family's, making it healthier:

"I kind of encouraged, forced, you know, my whole family to eat more baked, or broiled food. [...] My brother says that I helped to improve the nutrition of the whole family because I kind of encouraged everyone to eat healthier things, you know, I always prepare the salad and I do it myself, I do not let my mother make much fried food. [...] Today, because of me she (mother) kind of avoids having much fried food, she learned to eat salad. [...] Today I pick on her to have salad, I always prepare a lot of salad, then everyone, kind of, ended up helping one another. [...] Then the whole family helps one another so that nobody eats fried food. [...] I always make it for me and they end up eating, you know, there's no other way, broiled fish or grilled fish, so it's been really good, pretty good." (Carolina) 
Only one of the teenagers interviewed said she believes that her way of eating was not influenced by the dietary habits of her family, as described below:

"No, I don't think so (the way her family eats influenced her eating habits). I used to eat everything when I was little, like, vegetables. [...] In my mom's opinion I used to eat everything that was brought to me." (Daniela)

And only one of the teenagers interviewed said she considers her eating habits different from her family's, as testimony below:

"Aham (her family eating habitits is different from hers). [...] My father usually eats lunch alone in the living room, he likes to watch TV and this stuff, so then I have lunch with my mother. It's so fast, we don't even have time to look at each other." (Daniela)

The family's relationship with food is important because the timing of meals goes beyond its nutritional aspect. It is a time to share, beyond food, information, daily activities, messages, etc.. (Cobelo, 2004). According to Cordás et al. (1998), eating and emotions are closely related, so meals should be happen, whenever possible, with all family members, with set hours and a friendly and pleasant atmosphere.

\subsubsection{Healthy food}

To be considered a healthy diet it is necessary to be present a variety of foods according to the dietary habits, food availability and nutritional needs of each individual. It should also be considered the calorie intake and the inclusion of all macro and micronutrients in adequate quantities and proportions (Philippi \& Alvarenga, 2004).

According to the Ministry of Health of Brazil (Brasil, MS, 2005) a healthy diet should be based on "dieting practices taking social and cultural significance of food as a basic conceptual foundation", having the main characteristics: the respect and appreciation to the culturally identified dieting practices, since food has different cultural meanings; access guarantee, taste and affordability, because contrary to what has been socially constructed, a healthy diet is not expensive and should be tasty, it is varied: so it can provide different nutrients that the body needs; it is colorful, to ensure the variety especially in terms of vitamins and minerals, it is harmonious, with regard to quantity and quality of food consumed to the extent of appropriate nutrition considering the cultural, affective and behavioral aspects, and it is safe: from the physical chemistry and biological contamination standpoint and possible health risks.

In the description of the adolescents interviewed, the concept of healthy food seemed to us much more restricted. This is how they described it:

"Not much exaggerated, but not very restrained. [...] Eating a little of everything, at the set hours." (Daniela)

"Eating fruit, which I don't do, maintaining set hours to eat, practicing exercise to contribute with the diet, and eating a little of each food group, you know, a little carbohydrate, a little of everything, so that..., to balance the diet very well, you know. I think it's essential, but it is the most difficult thing to do as well." (Julia)

"Eating, but not eating too much, of course, avoiding lots of fried food, but eating modestly the things that you like, like, I eat potato chips, but only on the weekend, I eat chocolate, but only a little bit. But not quitting the things you like. But that's something I don't do." (Camila) 
"One that makes you feel good about yourself. Not only so, what's the use for a woman, who wants to lose weight, but the doctor tells her no, you will not lose weight because you have to eat this and this and that for days. Then the woman is going to be unhappy. This is not healthy. She will have that diet, her body will be healthy, but not her mind, which will not be satisfied with her . [...] Oh, I don't know, one that makes me not feel hungry. That's what I wanted. But yeah, I'm working on it." (Helena)

We see thus that these adolescents have an understanding of the principles of a balanced diet, although in most cases, they have attitudes that do not correspond to this understanding, since, as it was previoulsy seen, eating goes beyond nutritional dimensions, also involving emotional factors, being both socioeconomically and culturally influenced (Alvarenga, 2004).

\section{Discussion}

In recent years, $\mathrm{AN}$ and $\mathrm{BN}$ have become important topics of discussion in the Brazilian and world media. Characters in soap operas of the main open TV channel in Brazil carrying pictures of $\mathrm{AN}$ and $\mathrm{BN}$, headlines from the covers of magazines, newspapers and central theme of several shows, both on TV and radio, contributed to the increased audience flow.

This whole discussion brings a positive aspect: the dissemination of information about ED's by these vehicles of mass communication, because the earlier one detects an ED, the greater the chances of a good prognosis. As people's attention is called to the ED and the population becomes aware of its existence, symptoms and consequences, the more likely it is to be discovered in less time. Often seen as a teen mania, because of lack of information, the episodes reported by the media leads knowledge to the outsider public that $\mathrm{AN}$ and $\mathrm{BN}$ can kill.

In our research, we believe that the best people to provide information about ED's were the individuals affected by these diseases. Thus, in order to understand the meaning of the lived experience of people with ED's, particularly adolescent girls, we looked for them. This contact allowed us to know their experiences and feelings directly and indirectly related to their ED's.

Discovering what ED's are is not a very hard task, once there are numerous scientific articles and several books describing them. Our proposal was to show how these disorders are in the view of who is going through them.

In the contact with the interviewed teenagers, the availability to open the doors of their existence and share the history of their disorders and lives called our attention, even in the presence of suffering that emerged so many times in form of a deep silence or of tears that almost, or sometimes, were shed. The contact with these teenagers was enriching. The interviews allowed us to describe behaviors, attitudes, feelings and perceptions that guided our research.

An exacerbated concern with eating control is the common base of ED's, according to literature. This concern was also evidenced in our interviews, both with the teenagers that were having nutritional counseling and the ones that were not. There is still the intention of a diet considered healthy by them, which is not always their favorite, but it is, even though, adopted. 
We observed in our interviews that eating choices are usually done according to the amount of calories or with what gains less weight, but, besides these, the flavor, taste and desire also influence this choice. Some testimonies showed us that choices are made according to the guidance of the nutritionists, emphasizing the importance of this professional in the success of the treatment. However, in the episodes of binge eating, we observed that there is no rule for choosing.

Regarding to the number of meals had by the teenagers in our research, they quoted between three and eight a day, being distributed in breakfast, morning snack, lunch, afternoon snack, dinner, night snack, supper and "extras". Most of the interviewed teenagers considered their way of eating similar to their family's; some that the family's way of eating is similar to their own way, being different only to the amount. Others that their current eating habit had influence from the family's eating habit and one of them that she has influenced the family's eating habit, making it healthier.

This research allowed us to contemplate ED's by the prism of the relation with the food, confirming how this relation is connected to emotional matters. It has also shown us how it is to live with ED's in the view of the teenagers, trying to see these disorders according to their understanding and feelings. And, despite the theoretical knowledge and clinical practice with people with ED's, this "intersection" between nutrition and psychology led us also to see something relatively popular with a new vision.

In addition, this study, during its execution, caused significant changes in both personal and professional aspects, opening questions for future consideration.

With regard to the method adopted in this study, we believe that the choice of qualitative methods, focused on a phenomenological approach, was confirmed in fact to be the most appropriate according to the proposed objectives. The method adopted allowed us access to the content in a profound way, not generalized nor interpretative, as described by Heidegger (1989) " to let that which shows itself be seen from itself in the very way in which it shows itself from itself ".

\section{Final considerations}

This research, as noted, sought to understand the meaning of the lived experience of ED's instead of explaining them, since through the adopted phenomenological perspective, it is the understanding of the phenomenon that enables us to cover a whole in its multiple dimensions. Thus, it provided us to show you how it is to live with ED's in the vision of each of the seven adolescents interviewed.

But we can not stop here: it is essential to have more studies on this topic, especially providing space to people with ED's who have so much to say. Of great importance also is the information and disclosures about these ED's, as well as about the appropriate treatments and the right professionals to help in these cases, in an attempt to prevent that the suffering of those affected go unnoticed and last for too long - or even worse - lead to a tragic outcome.

\section{References}

Alvarenga, M. \& Larino, M. A. (2002). Terapia nutricional na anorexia e bulimia nervosas. Revista Brasileira de Psiquiatria, Vol.24, No.3, (December 2002) 
Alvarenga, M. (2004). A mudança na alimentação e no corpo ao longo do tempo. In: Philippi, S. T. \& Alvarenga, M. Transtornos alimentares: uma visão nutricional, Manole, Barueri

Amatuzzi, M. M. (1996). Apontamentos acerca da pesquisa fenomenológica. Estudos de Psicologia, Vol.13, No.1, pp. 5-10

Appolinário, J. C. \& Claudino, A. M. (2000). Transtornos alimentares. Revista Brasileira de Psiquiatria, Vol.22, No.2, (December 2000)

Assumpção Junior, F. B. (2004). Prefácio. In: Busse, S. de R. (org.). Anorexia, bulimia e Obesidade, Manole, Barueri

Bacaltchuck, J. \& Appolinário, J. C. (2005). Neurobiologia. In: Claudino, A. de M. \& Zanella, M. T. Guia de Transtornos Alimentares e Obesidade. Manole, Barueri, pp. 3-23.

Bandeira, C. R. S. et al. (2000). Hábitos Alimentares na Adolescência. Pediatria Moderna, Vol.36, No.11, (November 2000), pp.724-734

Beumont, P. J. V. (2002). The clinical presentation of anorexia and bulimia nervosa. In: Fairburn, C. G. \& Brownell, K. D. Eating disorders and obesity: a comprehensive handbook. (edition 2), The Guilford Press, Nova York

Brasil. Ministério da Saúde (MS). O que é uma alimentação saudável? Considerações sobre o conceito, princípios e características: uma abordagem ampliada. 26.11.2006, Available from:http://dtr2004.saude.gov.br/nutricao/documentos/o_que_e_alimentacao_sa udavel.pdf

Castro, J.M. \& Goldstein, S. (1995). Eating attitudes and behaviors of pre- and postpubertal females: clues to the etiology of eating disorders. Physiology \& Behavior, Vol.58, No.1, pp. 15-23

Chipkevitch, E. (1995). A dimensão psicossocial. Puberdade e adolescência: aspectos biológicos, clínicos e psicossociais, Roca, São Paulo

Cintra, I. de P. \& Fisberg, M. (2004). Mudanças na alimentação de crianças e adolescentes e suas implicações para a prevalência de transtornos alimentares. In: Philippi, S. T. \& Alvarenga, M. Transtornos alimentares: uma visão nutricional, Manole, Barueri

Cobelo, A. W. (2004). O papel da família no comportamento alimentar e nos transtornos alimentares. In: Philippi, S. T. \& Alvarenga, M. Transtornos alimentares: uma visão nutricional, Manole, Barueri

Conde, W. L. \& Monteiro, C. A. (2006). Valores críticos do índice de massa corporal para classificação do estado nutricional de crianças e adolescentes brasileiros. Jornal de Pediatria do Rio de Janeiro, Porto Alegre, Vol. 82, No. 4

Coppe, Â. A. F. (2001). A vivência em grupos de encontro: um estudo fenomenológico de depoimentos. Dissertação (Mestrado), Universidade Federal do Rio de Janeiro.

Cordás, T. A. et al. (1998). Anorexia e bulimia - o que são? Como ajudar?, Artes Médicas, Porto Alegre

Cordás, T. A. (2004). Transtornos alimentares: classificação e diagnóstico. Revista de Psiquiatria Clínica, São Paulo, Vol.31, No.4

Cordás, T. A. \& Salzano, F. T. \& Rios, S. R. (2004). Os transtornos alimentares e a evolução no diagnóstico e no tratamento. In: Philippi, S. T. \& Alvarenga, M. Transtornos alimentares: uma visão nutricional, Manole, Barueri

Devoraes, A. R. \& Fagundes, U. (2005). Avaliação e orientação nutricional. In: Claudino, A. de M. \& Zanella, M. T. Guia de transtornos alimentares e obesidade, Manole, Barueri 
Dietz, W. H. (1990). You are what you eat - what you eat is what you are. Journal of Adolescent Health, Vol.11, pp. 76-81

DSM-IV-TR (2002). Manual Diagnóstico E Estatístico De Transtornos Mentais (4 edition rev.), ArtMed, Porto Alegre

Dunker, K. L. L. \& Philippi, S. T. (2003). Hábitos e comportamentos alimentares de adolescentes com sintomas de anorexia nervosa. Revista de Nutrição, Campinas, Vol.16, No.1, (January - March 2003)

Eisenstein, E. \& Coelho, K. \& Coelho, S. \& Coelho, M. (2000). Nutrição na adolescência. Jornal de Pediatria, Rio de Janeiro, Vol.76, s.3, pp. 263-274

Ferreira, A. B. de H. (1993). Minidicionário da Lingua Portuguesa (3 edition), Nova Fronteira, Rio de Janeiro

Fischer, M. et al. (1995). Eating disorders in adolescents: a background paper. Journal of Adolescent Health Care, New York, Vol.16, No.6, pp. 420-437

França, C. (1989). Psicologia fenomenológica: uma das maneiras de se fazer, Editora da Unicamp, Campinas

Heidegger, M. (1989). Ser e Tempo (Part I), Vozes, Petrópolis

Holanda, A. F. (2002). O resgate da fenomenologia de Husserl e a pesquisa em psicologia. Tese (doutorado) - Universidade Católica de Campinas

Holanda, A. F. (2003). Pesquisa Fenomenológica e Pesquisa Eidética. In: Bruns, M. A. T. \& Holanda, A. F. Psicologia e fenomenologia: reflexões e perspectivas, Alínea, Campinas

Jauregui, L. I. \& Bolanos R. P. (2009). Choice of diet in patients with anorexia nervosa. Nutrición Hospitalaria, V.24, No.6, pp628-687

Juste, M. (2004). Quando comer é um problema. 21.09.2004, Available from: http:/ / revistagalileu.globo.com/Galileu/0,6993,ECT705249-1718,00.html

Martins, J \& Bicudo, M. A. V. (2003). A pesquisa qualitativa em psicologia: fundamentos e recursos básicos, (3 edition), Centauro, São Paulo

Moreira, D. A. (2002). O método fenomenológico na pesquisa, Pioneira Thomson, São Paulo

Nunes, M. A. et al. (2003). Prevalence of abnormal eating behaviours anda inappropriate methods of weight control in young women from Brazil: a population-based study. Eating Weight Disorders, Vol.8, No.2, pp. 1-7

Philippi, S. T. (1999). Guia Alimentar para o ano 2000. In: Angelis, R. C. Fome oculta: impacto para a população do Brasil, Atheneu, São Paulo

Philippi, S. T. et al. (2000). Alimentação saudável na infância e na adolescência. In.: Silva. M. V. et al. Curso de Atualização em alimentação para professores da rede pública de ensino. Escola Superior de Agricultura Luiz de Queiroz (Esalq), Piracicaba

Philippi, S. T. \& Alvarenga, M. (2004). Alimentação saudável: princípios e recomendações. In: Philippi, S. T. \& Alvarenga, M. Transtornos alimentares: uma visão nutricional, Manole, Barueri

Prieto, I. R. (2011). Elección dietética de familiares de pacientes com transtornos de la conducta alimentaria. Transtornos de la Conducta Alimentaria, 13, pp.1384-1415

Vieira, V. C. R. \& Priore, S. E. \& Ribeiro, S. M. R. et al. (2002). Perfil socioeconômico, nutricional e de saúde de adolescentes recémingressos em uma universidade pública brasileira. Revista de Nutrição, Vol.15, No.3, pp. 273-282

World Health Organization (WHO). BMI Classification. 18.09.2006, Available from: http://www.who.int/bmi/index.jsp?introPage=intro_3.html 
World Health Organization (WHO). Child and adolescent health and development. 11.10.2005, Available from:

http://www.who.int/childadolescenthealth/OVERVIEW/AHD/adh_over.htm 


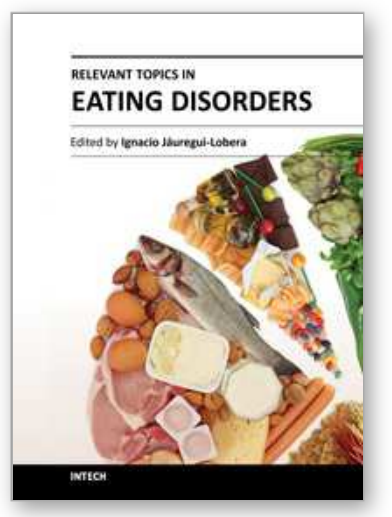

\author{
Relevant topics in Eating Disorders \\ Edited by Prof. Ignacio Jáuregui Lobera
}

ISBN 978-953-51-0001-0

Hard cover, 390 pages

Publisher InTech

Published online 22, February, 2012

Published in print edition February, 2012

Eating disorders are common, frequently severe, and often devastating pathologies. Biological, psychological, and social factors are usually involved in these disorders in both the aetiopathogeny and the course of disease. The interaction among these factors might better explain the problem of the development of each particular eating disorder, its specific expression, and the course and outcome. This book includes different studies about the core concepts of eating disorders, from general topics to some different modalities of treatment. Epidemiology, the key variables in the development of eating disorders, the role of some psychosocial factors, as well as the role of some biological influences, some clinical and therapeutic issues from both psychosocial and biological points of view, and the nutritional evaluation and nutritional treatment, are clearly presented by the authors of the corresponding chapters. Professionals such as psychologists, nurses, doctors, and nutritionists, among others, may be interested in this book.

\title{
How to reference
}

In order to correctly reference this scholarly work, feel free to copy and paste the following:

Arlene Leite Nunes (2012). The Relationship with Food in Eating Disorders, Relevant topics in Eating Disorders, Prof. Ignacio Jáuregui Lobera (Ed.), ISBN: 978-953-51-0001-0, InTech, Available from: http://www.intechopen.com/books/relevant-topics-in-eating-disorders/the-relationship-with-food-in-eatingdisorders

\section{INTECH}

open science | open minds

\section{InTech Europe}

University Campus STeP Ri

Slavka Krautzeka 83/A

51000 Rijeka, Croatia

Phone: +385 (51) 770447

Fax: +385 (51) 686166

www.intechopen.com

\section{InTech China}

Unit 405, Office Block, Hotel Equatorial Shanghai

No.65, Yan An Road (West), Shanghai, 200040, China

中国上海市延安西路65号上海国际贵都大饭店办公楼 405 单元

Phone: +86-21-62489820

Fax: $+86-21-62489821$ 
(C) 2012 The Author(s). Licensee IntechOpen. This is an open access article distributed under the terms of the Creative Commons Attribution 3.0 License, which permits unrestricted use, distribution, and reproduction in any medium, provided the original work is properly cited. 